\title{
PROCEEDINGS
}

or

\section{THE ROYAL SOCIETY}

OF

\section{EDINBURGH.}

\author{
VOL. XII.
}

NOVEMBER 1882 To JULY 1884.

\author{
EDIN B U R G H \\ PRINTED BY NEILL AND COMPANY. \\ MDCCCLXXXIV.
}




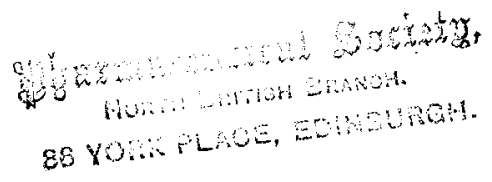




\section{CONTENTS.}

PAGE

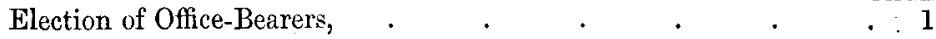

President's Address, . $\quad$. $\quad$. $\quad$. $\quad$. $\quad$. $\quad$. 2

Dr Guébhard's Electro-Chemical Method of Figuring Equipotential

Lines. By Rev. Dr W. R. Smith, .

Message from the Nautical Almanac Office, in reference to the Transit of Venus, December 6, 1882. Communicated by the AstronomerRoyal,

On the Laws of Motion. Part I. By Professor Tait,. • $•{ }^{-}$

On Illegitimacy in Scotland. By George Seton, M.A., Oxon, . 18

- On the Absorption of Low Radiant Heat by Gaseous Bodies. By

Professor MacGregor,

Note on the Compressibility of Water. By Professor Tait, $: 24$

Note on an Application of Mendeleieff's Law to the Heats of Combination of the Elements with the Halogens. By Mr A. P. Laurie. Communicated by Professor Crum Brown, . . . 46

The Diurnal Variation of the Force of the Wind in the Open Sea and near Land. By Alexander Buchan, M.A., . . . . 47

On the Semitic and Greek Article. By the Rev. Dr Teape, $\quad 47$

On the Nature of Solution. By W. W. Nicol, M.A., B.Sc., . $\quad 47$

On the Relative Electro-Chemical Positions of Wrought Iron, Steels,

Cast Metal, \&c., in Sea Water and other Solutions. By Thomas Andrews, Assoc. M. Inst. C.E., F.C.S. Communicated by Prof. Crum Brown,

Observations of the Rainband from June 1882 to January 1883 . By Hugh Robert Mill, B.Sc., F.C.S. Communicated by Professor Tait. (Plate I.), · • • •

The Theory of Monopressures applied to Rhythm, Accent, and Quantity. By the Rev. J. L. Blake. Communicated by Prof.

Crum Brown, . . . . . . . . 56

On the Effect of Oil on a Stormy Sea. By Mr John Aitken, $\quad . \quad 56$

Comnunication from the Astronomer-Royal for Scotland. Read by Professor Tait, . . . . . . .

Diagnoses plantarum novarum Phanerogamarum Socotrensium, etc.; quas elaboravit Bayley Balfour, Scientiæ Doctor et in Universitate Glascuensi rerum botanicarum regius professor. Pars Tertia, . 76

On Scientific Method in the Study of Language. By Emeritus Prof.

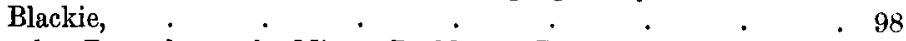

Further Remarks on the Mirage Problem. By Professor Tait, $; \quad$. 98 
On Ancient Tenure of Land in Scotland. By Mr G. Auldjo Jamieson,

On the Microscopical Appearances of Striped Muscular Fibre during

Relaxation and Contraction. By Professor Rutherford, . . . $12 \overline{6}$

Election of Honorary Fellows, $\quad . \quad$. . . . 126

On the so-called Bicipital Ribs. By Professor William Turner, $\quad 127$

Oscillations and Waves in an Adynamic Gyrostatic System. By Sir

William Thomson, . . . . . . . . . 128

On Gyrostatics. By the Same, . $\quad$. $\quad . \quad$. $\quad$. 128

On the Dynamical Theory of Dispersion. By the Same, . $\quad .128$

On the Impossibility of Inverted Images in the Air. By Edward

Sang,

On the Thermo-electric Positions of pure Rhodium and Iridium.

By Professor Tait, . . . . . . . 136

Observations on the Growth of Wood in Deciduous and Evergreen

Trees. By the late Sir R. Christison, Bart., and Dr Christison, . 136

The Variation of Temperature, with Sun-Spots. By Mr A. Buchan, 136

On some Laboratory Arrangements. By Dr John Gibson, . . 137

On the Thermo-electric Position of pure Cobalt. By Professor Tait, 141

Transmission of Power by Alternate Currents. By Professor George

Forbes,

On the Homology of the Neural Gland in the Tunicata with the

Hypophysis Cerebri. By W. A. Herdman, D.Sc., F.L.S., Pro-

fessor of Natural History in University College, Liverpool, . 145

On the Quaternion Expression of Finite Displacements of a System of Points of which the Mutual-Distances remain Invariable. By Gustave Plarr, Docteur ès Sciences. Communicated by Prof. Tait, 151

On some Properties of the Line of Simple Flexure. By Edward

Sang, C.E. (Plates I.*-III.), . . . . .

On the Measurement of Resistance in Electrolytes. By Cargill G.

Knott, D.Sc., F.R.S.E., . . . . 178

The Electrical Resistance of Hydrogenised Palladium. By Cargill

G. Knott, D.Sc., F.R.S.E., . . . . . . . 181

Note on Plane Algebra. By A. Macfarlane, M.A., D.Sc., . $\quad .184$

On Heat-Conduction in Heterogeneous Bodies, as modified by the

Peltier and Thomson effects. By Professor Tait, . . . 186

Note on the Thermo-electric Position of pure Ruthenium. By Prof.

Tait, . . . . . . . . 186

At the request of the Council Professor Geikie delivered an Address

on Recent Advances in European Pleistocene Geology, . . 186

On the Moon and the Weather. By John Aitken, . . . 187

The Acids of Opium. By D. B. Dott, : : 189

Direct Observations of the Effect of Pressure on the Maximum

Density-Point of Water. By Professor Tait, . . . 192

The Diurnal Oscillations of the Barometer. Part II. By Mr'A.

Buchan, . $. \quad . \quad . \quad . \quad . \quad . \quad . \quad . \quad 193$

Ninth Report of the Boulder Coinmittee. Communicated by $\mathrm{Mr}$

Milne Home, . . . . . . . . . . 193 
On a new Entozoon (Pentastomum protelis) from the Mesentery of Proteles cristatus, Sparrmann. By W. E. Hoyle, M.A. (Oxon.), F.R.S:E., Naturalist to the "Challenger" Expedition Commission, 219

Bright Clonds on a Dark Night Sky. By the Astronomer-Royal for Scotland,

Mathematical Note. By Mr A. H. Anglin, .

Note on the Compressibility of Water, Sea-Water, and Alcohol, at

High Pressures. By Professor Tait,

Note on the little $b$ group of lines in the Solar Spectrum and the new College Spectroscope. By the Astronomer-Royal for Scotland, . 225

On Superposed Magnetisms in Iron and Nickel. By Prof. C. G. Knott, D.Sc, 223 Further Note on the Maximum Density-Point of Water. By Prof. Tait,

On Surface Emissivity. By Professor 'Tait, .

On a proposed Edinburgh Marine Station for Biological Research at Granton Quarry. By Mr John Murray, . . . .

On Work done on board H.M.S. "Triton" in the Faroe Channel during the Summer of 1882. By Mr John Murray,

On the Pennatulida dredged in the Faroe Channel during the Cruise of H.M.S. "Triton" in August 1882. By Prof. A. M. Marshall. Communicated by Mr John Murray,

On the Asteroidea dredged in the Faroe Channel during the Cruise of H.M.S. "Triton" in August 1882. By Mr W. Percy Sladen, F.L.S., F.G.S. Communicated by Mr John Murray,

On the Pycnogonida dredged in the Faroe Channel during the Cruise of H.M.S. "Triton" in August 1882. By Dr P. P. C. Hoek. Communicated by Mr John Murray,

On the Crustacea dredged in the Faroe Channel during the Cruise of H.M.S. "Triton" in 1882. By Rev, A. M. Norman, D.C.L. Communicated by Mr John Murray,

On the Tunicata dredged in the Faroe Channel during the Cruise of H.M.S. "Triton" in August 1882. By Professor W. A. Herdman, 231

On the Proofs of Proportionality of Emissive and Absorptive Power. By Professor Tait, .

A Contribution to the Chemistry of Nitroglycerine. By Matthew Hay, M.D., Assistant to the Professor of Materia Medica in the University of Edinburgh. Communicated by Prof. Crum Brown, 234

The Elementary Composition of Nitroglycerine. By Matthew Hay, M.D., and Orme Mason, M.A., B.Sc. Communicated by Prof. Crum Brown, . . . . . . . . . . 234

President's Closing Remarks, . . . . . . . $\quad .235$

Mathematical Note. By Mr R. H. Hallam Anglin, M.A., LL.B., M.R.I.A.

Election of Office-Bearers,

An Essay upon the Limitations in Time of Conscious Sensations. By John B. Haycraft, M.B. Edin., F.R.S.E., \&c.; Professor of Physiology in the Mason Science College, and Lecturer on Physiology at Queen's College, Birmingham, 
The Old English Mile. By Wm. Flinders Petrie. Communicated by Professor Robertson Smith, . . . . .

A Re-Statement of the Cell Theory, with Applications to the Morphology, Classification, and Physiology of Protists, Plants, and Animals. Together with an Hypothesis of Cell-Structure, and an Hypothesis of Contractility. By Patrick Geddes. (Plate IV.), . 266 On the Change in the Peltier Effect due to Variation of Temperature. By Albert Campbell. Communicated by Professor Tait,

On the Problem of the Lathe-Band, and on Problems therewith connected. By Edward Sang,

Notes on the Madi or Moru Tribe of Central Africa. By Robert W. Felkin, F.R.S.E., F.R.G.S., Fellow of the Anthropological Societies of London and Berlin, \&c. (Plate V.), . . . .

On the Crinoidea of the North Atlantic between Gibraltar and the Faroe Islands. By P. Herbert Carpenter, D.Sc. (Camb.), Assistant Master at Eton College. With some Notes on the Myrostomida, by Prof. L. von Graff, Ph.D. Communicated by Mr John Murray, 353

On the Structure of the Pitcher in the Seedling of Nepenthes, as compared with that in the Adult Plant. By Prof. Alexander Dickson, M.D.,

Approximation to the Roots of Cubic Equations by help of Recurring Chain Fractions. By Edward Sang, LL.D., . . . 387

The Researches of M. E. de Jonquières on Periodic Continued Fractions. By Thomas Muir, M.A., . . . . . . 389

Additional Note. By the Same, . $\quad$. $\quad . \quad$. $\quad .398$

New Forms of Nerve Terminations in the Skin of Mammals. By George Hoggan, M.B. (Edin.). Communicated by Prof. Turner, 400 Diagnoses Plantarum novarum Phanerogamarum Socotrensium, etc.; quas elaboravit Bayley Balfour, Scientiæ Doctor et in Universitate Glascuensi rerum botanicarum regius Professor. Pars quarta (Supplementum)

Abstract Report on the "Porcupine" Tunicata. By Professor W. A. Herdman,

Arrangement of the Metals in an Electro-Frictional Scale. By A. Macfarlane, D.Sc., .

On Distant Vision. By E. E. Maddox Esq. Communicated by Professor Crum Brown,

On the Formation of Small Clear Spaces in Dusty Air. By $\mathrm{Mr}$ John Aitken,

The Remarkable Sunsets. By Mr John Aitken,

President's Address, giving a Review of the Hundred Years' History of the Society,

On the Microscopic Characters of Volcanic Ashes and Cosmic Dust, and their Distribution in the Deep-Sea Deposits. By Mr John Murray and M. l'Abbé Renard. Communicated by Mr John Murray,

On the Nomenclature, Origin, and 1)istribution of Deep-Sea Deposits. By John Murray and M.'I'Abbé Renard. Communicated by John Murray, . . . . . . 
Note on a large Crystal of Calc-spar found in Lough Corrib by Professor Tait. By M. l'Abbé Renard,

On the Need for Decimal Subdivisions in Astronomy and Navigation, and on Tables requisite therefor. By Edward Sang, LL.D., 533

An Electro-Magnetic Declinometer. By A. Tanakadaté, Assistant to the Professor of Physics in the University of Tokio, Japan. Communicated by Prof. J. A. Ewing, University College, Dundee, ' 544 On an Equation in Quaternion Differences. By Professor Tait, .561 On Vortex Motion. By Professor Tait, . . . . . 562

Award of the Keith, Makdougall-Brisbane, and Neill Prizes, . 562 On Efficiency of Clothing for maintaining Temperature. By Sir W. Thomson,

On the Law of Inertia; the Principle of Chronometry; and the Principle of Absolute Clinural Rest, and of Absolute Rotation. By Professor James Thomson, LL.D., D.Sc., C.E.,

On a Modification of Gauss's Method for determining the Horizontal Component of Terrestrial Magnetic Force, and the Magnetic Moments of Bar Magnets, in Absolute Measure. By Sir William

- Thomson,

On the Phenomenon of "Greatest Mirdle" in the Cycle of a Class of

Periodic Continued Fractions. By Thomas Muir, M.A., F.R.S.E., 578

The Old Red Sandstone Volcanic Rocks of Shetland. By Messrs

B. N. Peach and John Horne, of the Geological Survey of Scotland, 593

On the Principles of Economics. Part I., Mathematical. Part II.,

Physical. By Mr P. Gedles, . . . . . . . 593

An Integrating Hygrometer. By Professor C. Michie Smith, . 593

On the Philosophy of Language. By Emeritus Professor Blackie, . 594

On the Principles of Economies. Part III., Biological and Psycho-

logical. By Mr P. Geddes, . . . . . . 594

Note on a New Form of Galvanometer. By Prof. James Blyth, . 594

On Galvanic Currents passing through a very Thin Stratum of an

Electrolyte. By Professor H. von Helmbolty, . . . .596

On Cosmic Dust. By M. l'Abbé Renard, . . . . 599

Esempio del metodo di dedurre una superficie da una figura piana, dal Professore Luigi Cremona, . . . . . .

On the Construction of the Canon of Logarithmic Sines. By Edward Sang, LL.D., . $\quad . \quad$. $\quad . \quad$. $\quad . \quad 601$

On Stichocotyle nephropis, a new Trematode. By Mr J. T. Cunningham, B.A. Communicated by Mr John Murray, . . . . 619

Scottish Vital Statistics. By Mr George Seton, Advocate, M.A. Oxon.,

Experiments on the Chief Disinfectants of Commerce, with a view of ascertaining their Power of Destroying the Spores of the Anthrax bacillus. By A. Winter Blyth, Medical Officer of Health and Public Analyist. Communicated by Professor Turner, .

Sur la Réduction des Intégrales Hyperelliptiques, extrait d'une lettre adressée à M. le Professeur Chrystal, par M. Hermite, . 
At the request of the Council, Professor Schuster give an Address on the Discharge of Electricity through Gases, with Experimental Illustrations,

The Enumeration, Description, and Construction of Knots with fewer than Ten Crossings. By the Rev. T. P. Kirkman, F.R.S. Communicated by Professor Tait,

On Knots. Part II. By Professor Tait, . . . . . 647

Second Note on the Remarkable Sunsets. By Mr John Aitken, . 647

Thermometer Screens. By Mr John Aitken. (Plate VI.), . . 661

Abstract of Paper on Micrometrical Measures of Gaseous Spectra.

By Professor C. Piazzi Smyth, . . . . .

On the Computation of Recurring Functions by the aid of Chain-

Fractions. By Edward Sang, LL.D., . . . . 703

On Extensions of Euclid I. 47. By Mr A. H. Anglin, . . 703

Report on the Ophiuroidea of the Faroe Channel, mainly collected

by H.M.S. "Triton" in Angust 1882, with some Remarks on the Distribution of the Order. By Mr W. E. Hoyle, M.A. (Oxon.), M.R.C.S., Naturalist to the "Challenger" Commission. (Plate

On the Principles of Economics. By Mr P. Geddes. Part V., Psychological,

A Problem on Point-Motions for which a Reference-Frame can so exist as to have the Motions of the Points relative to it, Rectilinear and Mutually Proportional. By Professor James Thomson, . 730

Note on Reference Frames. By Professor Tait, . . . . 743

Note on the Occurrence of Drifted Trees in Beds of Sand and Gravel at Musselburgh. By Professor James Teikie, LL.D., F.R.S., . 745

On a Special Class of Partitions. By Professor Tait, . . 755

Observations on a Green Sun, and Associated Phenomena. By Prof.

C. Michie Smith, . . . . . . . 755

Analysis of the Principles of Economics. Part V., Psychological.

By Mr P. Geddes, . . . . . . . . . . 755

On a Singular Electrical Result. By Mr Harry Rainy. Communicated by Professor Tait, . . . . . . . . . 756

Observations on Coral Reefs and Calcareous Formations of some of the Islands in the Solomon Group. By H. B. Guppey, M.D., H.M.S. "Lark," with Notes by Mr John Murray. Communicated by $\mathrm{Mr}$ John Murray,

Further Note on the Compressibility of Water. By Professor Tait, 757

Critical Note on the latest Theory in Vertebrate Morphology. By Mr J. T. Cunningham, B.A.,

Tenth and Final Report of the Boulder Committee ; with Appendix, containing an Abstract of the Information in the Nine Annual Reports of the Committee ; and a Summary of the Principal Points apparently established by the information so received. (Plates VIII. to X.),

Remarks by Mr Milne Home on presenting the Tenth Report of Boulder Committee, 
Notice of Two Localities for Remarkable Gravel Banks or Kaimes, and Boulders, in the West of Scotland, in Supplement of the Boulder Committee's Tenth Report. By David Milne Home, LL.D. (Plates XI. to XIII.), . . . . .

On the Periodic Variation of Temperature in Tidal Basins. By Hugh Robert Mill, B.Sc.. F.C.S. Communicated by Professor Crum Brown. (Plate XIV.), . . . . .

On the Isothermals and Adiabatics of Water near the Maximum Point. By Mr W. Peddie. Communicated by Professor Crum Brown, . . . . . . . . . 933 Review of the Session, by the President, . . . . . . 937 Address from the Society to the University on the occasion of the Tercentenary, . . . . . . . . 940 An Analysis of the Principles of Econonics. By Patrick Geddes, 943 Donations to the Library, . . . . . . . . . 981 Index, . $\quad . \quad . \quad . \quad . \quad . \quad .1000$ 